IZA DP No. 5951

Are Occupations Paid What They Are Worth?

An Econometric Study of Occupational

Wage Inequality and Productivity

Stephan Kampelmann

François Rycx

September 2011 


\title{
Are Occupations Paid What They Are Worth? An Econometric Study of Occupational Wage Inequality and Productivity
}

\author{
Stephan Kampelmann \\ Université de Lille, CLERSE \\ and SBS-EM (DULBEA) \\ François Rycx \\ Université Libre de Bruxelles, \\ SBS-EM (CEB, DULBEA) and IZA
}
Discussion Paper No. 5951
September 2011

\author{
IZA \\ P.O. Box 7240 \\ 53072 Bonn \\ Germany \\ Phone: +49-228-3894-0 \\ Fax: +49-228-3894-180 \\ E-mail: iza@iza.org
}

Any opinions expressed here are those of the author(s) and not those of IZA. Research published in this series may include views on policy, but the institute itself takes no institutional policy positions.

The Institute for the Study of Labor (IZA) in Bonn is a local and virtual international research center and a place of communication between science, politics and business. IZA is an independent nonprofit organization supported by Deutsche Post Foundation. The center is associated with the University of Bonn and offers a stimulating research environment through its international network, workshops and conferences, data service, project support, research visits and doctoral program. IZA engages in (i) original and internationally competitive research in all fields of labor economics, (ii) development of policy concepts, and (iii) dissemination of research results and concepts to the interested public.

IZA Discussion Papers often represent preliminary work and are circulated to encourage discussion. Citation of such a paper should account for its provisional character. A revised version may be available directly from the author. 
IZA Discussion Paper No. 5951

September 2011

\title{
ABSTRACT \\ Are Occupations Paid What They Are Worth? An Econometric Study of Occupational Wage Inequality and Productivity*
}

\begin{abstract}
Labour economists typically assume that pay differences between occupations can be explained with variations in productivity. The empirical evidence on the validity of this assumption is surprisingly thin and subject to various potential biases. The authors use matched employer-employee panel data from Belgium for the years 1999-2006 to examine occupational productivity-wage gaps. They find that occupations play distinct roles for remuneration and productivity: while the estimations indicate a significant upward-sloping occupational wage-profile, the hypothesis of a flat productivity-profile cannot be rejected. The corresponding pattern of over- and underpayment stands up to a series of robustness tests.
\end{abstract}

JEL Classification: J24, J31, J44

Keywords: labour productivity, wages, occupations, production function, matched employer-employee data

Corresponding author:

François Rycx

SBS-EM (CEB, DULBEA) \& IZA

Université Libre de Bruxelles

CP 114/02, Avenue F.D. Roosevelt, 50

B-1050 Brussels

Belgium

E-mail: frycx@ulb.ac.be

*We would like to thank Statistics Belgium for giving access to the data. The usual disclaimer applies. 


\section{Introduction}

According to standard economic theory, the competition among workers and among firms leads to relative factor prices that reflect economic forces: the closer labour markets are to perfect competition, the closer factor prices are to the value of the marginal product of labour and labour market inequality equal to differences in productivity between workers.

This explanation of pay inequality has been challenged by empirical and theoretical work on labour markets: 'Sociologists have long been dissatisfied with [neoclassical and human capital theory], particularly with their silence about the many forces that generate a mismatch between marginal productivity or skills and wages in the ever-present short run' (Weeden, 2002, p. 71). Indeed, a range of labour market theories hypothesize sources of inequality other than labour productivity, such as collective action, labour market institutions or the use of power and authority to obtain economic advantages (for overviews on standard sociological theories on labour market inequality see Kalleberg and Sørensen (1979), Berg (1981), Müller and Schmid (2003)). Although each of these theories on inequality focuses on distinct social processes, they appear to have in common that they associate labour market inequality at least implicitly to an element of 'unearned', or 'unjust' allocation of resources to dominant groups. On the other hand, economists have also developed explanations of differences between productivity and wages without having to abandon the assumptions of individual rationality and profit-maximizing firms. In this literature, productivity-wage gaps are thought to be rational strategies with which firms address a range of market distortions (Lazear and Shaw, 2007).

The abundance of theories on productivity-wage gaps is not matched by a corresponding body of empirical literature. In fact, empirical studies typically refrain from measuring productivity of occupations. Instead, occupational categories are distinguished according to their average educational attainments, on-the-job training, work experience etc., which are often lumped together under the catch-all term 'skills'. This boils down to using variables such as educational attainment as proxies for labour productivity, one of the basic assumptions of human capital theory (cf. Mincer, 1958, 1970). Such an approach can be problematic: without any direct measure of occupational productivity it is unclear to what extent the selected variables are acceptable proxies. Instead of using skill proxies, we measure the marginal contributions of different occupational categories to firm-level added-value econometrically. This approach has been pioneered by Gottschalk (1978), who observed systematic differences between productivity and earnings for occupations (see Section 2.2). 
Improved data and recent developments in measurement techniques, especially the identification and treatment of different forms of bias, have created the need and the tools to put Gottschalk's results to an updated test. We take advantage of access to detailed matched employer-employee panel data from Belgium for the years 1999-2006 to study the impact of the occupational composition of a firm on wages and productivity.

\section{Literature Review}

\subsection{Theoretical Literature on Productivity-Wage Gaps}

Many of the theories predicting productivity-wage gaps are either formulated without referring to specific categories of workers or focus on gaps based on categories other than occupations, like age or authority. In this section, we show how some of the more prominent theories on mismatches between productivity and remuneration can be applied to the case of occupations.

\subsubsection{Theories Based on Efficiency and Individual Rationality}

A first set of theories emphasises the role of hiring and training costs. These costs can be considered as 'quasi-fixed' costs since they do not vary with the length of the employment period. To amortize quasi-fixed costs, a profit-maximising firm pays a wage below the marginal product (Oi, 1962). This effect can be further amplified if the skills acquired through training are firm-specific (cf. Acemoglu and Pischke, 1999, pp. 559-561). Quasi-fixed costs and skill-specificity are likely to differ across occupations and we would expect lower-thanmarginal-product wages for occupations requiring intensive training and/or specific skills.

Another strand of theories that can be applied to occupations uses more sophisticated assumptions about the individual utility function of the worker, notably by analysing the ramifications of two types of utility interdependence. First, utility may depend not only on one's own, but also on other people's wages (Hamermesh, 1975). As a consequence, high wage inequality could lead to lower utility and lower effort. Workers may perceive wage inequality as 'unfair' and decrease their efforts accordingly (Akerlof and Yellen, 1990; Levine, 1991). Hence, there is an efficiency argument in paying high-productivity occupations in a firm below and low-productivity occupations above their marginal products so as to compress the overall wage structure. The second type of interdependence is slightly more 
complex as it takes into account not only wages, but also non-monetary elements of so-called hedonic wages (cf. Lazear and Shaw, 2007, pp. 102-105). According to this model, individual effort not only depends on the worker's relative wage, but also on her status within the firm. Status is interpreted as a good that can be purchased by foregoing a higher wage. The tradeoff between wage and status would lead to the same pattern of deviations from a productivitybased pay as in the first type of utility interdependence, i.e. a compressed wage structure (Frank, 1984). Since occupations clearly differ with respect to status, from an efficiency viewpoint we would expect that high-status occupations are therefore underpaid compared to their marginal product and that low-status occupations are overpaid.

These theories predict a compressed wage structure in which high-skilled/high-status occupations are under- and low-skilled/low-status occupations are overpaid relative to their respective marginal products. By contrast, tournament theory predicts a convex relationship between a worker's pay and her position in the firm's hierarchy, to the extent that workers at the top of the hierarchy might receive wages beyond their marginal products. Tournament theory interprets these high wages as 'prizes' in a contest between workers at lower strata of the firm's hierarchy. Lazear and Rosen (1981) argue that these prizes are part of an incentive mechanism to trigger investment in skills and effort from competing workers at lower levels of the hierarchy. For instance, 'the president of a corporation is viewed as the winner of a contest in which he receives the higher prize', but 'his wage is settled on not necessarily because it reflects his current productivity as president, but rather because it induces that individual and all other individuals to perform appropriately when they are in more junior positions' (Lazear and Rosen, 1981, p. 847). Whether this mechanism applies to our problem depends on the extent to which the prizes of tournaments are also associated with an occupational promotion. For instance, the winner of a tournament among a group of office clerks might be promoted to a management position. In this case the high wages of managers serve as prizes in a tournament among office clerks and can therefore exceed the manager's marginal product.

\subsubsection{Socio-Economic and Institutionalist Theories}

The literature on social norms and remuneration has also some relatively straightforward implications for occupational over- or under-payment with respect to productivity. Skott (2005) treats wage norms as endogenous, with past events shaping what is considered to be 'fair' wages. This creates a hysteresis of the wage structure, slow adjustment to productivity 
shocks and therefore potential deviations from productivity-based pay. Similarly, Doeringer and Piore (1985) view the related concepts of 'customs' and 'habit' as important factors in the determination of employment rules in their model of internal labour markets. They argue that besides efficiency considerations (employer's interests) and demands for stability and job security (employees' interests), strong customs render changes in pay rules difficult. Given that technological change over the past decades appears to be skill- and therefore to some extent also occupation-biased (Autor et al., 1998; Acemoglu, 2002), the hysteresis of social norms could lead to overpayment of occupations whose productivity has been negatively affected by technological change, and to underpayment of the occupations whose productivity increased. As a result, we would expect to find a compressed occupational wage structure.

Many institutional economists focus on collective processes that complement the analysis of market forces. Osterman et al. (2009) affirm that employment rules and systems 'are the result of a political process in which competing objectives and rationalities play out a contest' (Osterman et al., 2009, p.705). The occupational wage structure could reflect to some extent the competing objectives of occupations and their respective weights in internal decision-making processes of organisations. For instance, it seems plausible that any rent generated by the firm could be unequally distributed among occupational groups in light of apparent informational and power asymmetries across occupations. There is a parallel between this idea and the standard analysis of principal-agent problems: wages of occupations that cannot be controlled effectively by their principals (they have 'Managerial power') might be higher than predicted by the basic neoclassical model (Bebchuk and Fried, 2003).

\section{Empirical Literature}

Surprisingly, only few empirical studies have focused on occupational differences between productivity and earnings. The empirical work on wage compression, for instance, does not consider productivity-wage gaps between, but only within occupations (Scully, 1974; Frank, 1984). More recent econometric studies on productivity-wage comparisons have focused on categories like sex, ethnicity or age instead of occupations (Haegeland and Klette, 1999; Aubert and Crépon, 2003; Ilmakunnas and Maliranta, 2005; Cataldi et al., 2011; Cardoso et al., 2011; Dostie, 2011; Ilmakunnas and Ilmakunnas, 2011; Vandenberghe, 2011a,b; van Ours and Stoeldraijer, 2011). Other studies only include relatively broad occupational categories as control variables in wage and productivity equations (Hellerstein et al., 1999; Crépon et al., 2002; Hellerstein and Neumark, 2007; Göbel and Zwick, 2009). 
The empirical study on occupational pay differences by Weeden (2002) is therefore exceptional. Weeden measures to what extent occupational earnings inequality can be explained with activities directed at social closure, i.e. the construction by occupations of 'social and legal boundaries that [...] affect the rewards of their members' (Weeden, 2002, p. 59). Applied to our question, the basic idea of closure theory is that occupational groups engage in activities that shield them from external competition. In its simplest form, occupational closure can be seen as a form of rent seeking if closure yields monopoly rents to members of an occupation that restricts supply, for instance through a limited quota for licences needed to exercise in a profession (Sørensen, 1996, 2000). Weeden identifies a whole range of closure strategies: restricting the supply of practitioners, increasing diffuse demand for the services of the occupation, channelling demand to the occupation, and signalling quality of service (Weeden, 2002, p. 60). Her study concludes that 'not all occupations benefit equally from social closure. The professions, in particular, benefit more than other occupations' (Weeden, 2002, p. 92). Unfortunately, it is unclear to what extent Weeden's results actually describe productivity-wage gaps. Although the author is interested in 'the many forces that generate a mismatch between marginal productivity or skills and wages in the ever present short run' (p. 71), the particular set of closure strategies analysed in Weeden (2002) would not lead to such a mismatch. The reason for this is that strategies like 'restricting the supply of practitioners' are equivalent to a shift of the supply curve of an occupation. While it is true that this leads to higher rewards for members of the occupation, the value of their marginal product would rise accordingly and no mismatch between marginal productivity and wages could be observed.

The reference for empirical inter-occupational comparisons of productivity-wage differences remains Gottschalk's work from the late 1970s (Gottschalk, 1978). Comparing his estimation of marginal revenue products with median earnings, Gottschalk could not refute significant differences between productivity and earnings for a set of occupational groups (see Table 1), a finding later confirmed by Gottschalk and Tinbergen (1982). The overall conclusion of this study is that productivity differences appear to be inversely related to pay differences, a finding that has to our knowledge not been directly refuted in the empirical literature. Nevertheless, new data and recent developments in measurement techniques, especially the identification and treatment of various forms of bias, have created the need and the instruments to put Gottschalk's results to an updated test. This is the purpose of this article. 
[Insert Table 1 here.]

\section{A New Test for Occupational Productivity-Wage Gaps}

The test developed in this article is based on the estimation of a value-added function and a wage equation at the firm-level. The value-added function yields parameter estimates for the average marginal products for each occupation, while the wage equation estimates the respective impact of each occupation on the average wage paid by the firm. Given that both equations are estimated with the same set of firms and occupations, the parameters for marginal products and wages can be compared so that conclusions on occupational productivity-wage gaps can be drawn. This technique was pioneered by Hellerstein et al. (1999) and refined by Aubert and Crépon (2003), van Ours (2009), Göbel and Zwick (2009), van Ours and Stoeldraijer (2011) and others.

Equation (1) is a function linking a range of inputs of firm $i$ to its added value $Y_{i}$.

$$
Y_{i}=F\left(K_{i}, Q L_{i}\right)
$$

where $K_{i}$ represents the firm's capital stock and $Q L_{i}$ is a quality of labour term. The latter allows introducing a heterogeneous labour force into the value-added function.

There is an abundant econometric literature on the estimation of relationships as the one depicted in Equation (1). In an attempt to reflect more accurately the production process inside the firm, specialists in the field have proposed specifications allowing e.g. for production inefficiencies or different elasticities of substitution between the factors of production. Since our focus is not on the production process itself, but rather on the comparison between productivities and wages for a set of occupations, we use a simple CobbDouglas version of Equation (1), with substitution elasticities equal to one and the assumption of firms operating at the efficiency frontier. This restriction appears to be unproblematic as previous firm-level studies have shown that productivity coefficients obtained with a CobbDouglas structure are robust to other functional specifications (see, for instance, Hellerstein and Neumark, 2007; p. 49). Equation (2) is the basic (Cobb-Douglas) value-added function:

$$
\log \left(Y_{i}\right)=\log \left(A_{i}\right)+\alpha \log \left(K_{i}\right)+\beta \log \left(Q L_{i}\right)
$$


where $A_{i}$ is a constant. The parameters $\alpha$ and $\beta$ are the respective marginal productivities of each input factor. $Q L_{i}$ can be written as:

$$
Q L_{i}=L_{i}\left(1+\left(\theta_{i, j}-1\right) \sum_{j=1}^{G} \frac{L_{i, j}}{L_{i}}\right)
$$

where $L_{i}$ is the total labour force of the firm $i$ and $L_{i, j} / L_{i}$ the proportion of occupation $j$ in the total labour force. Substituting Equation (3) into (2) allows for different marginal productivities for each of the $G$ occupations. If for occupation $j$ the parameter $\theta_{j}$ is bigger (smaller) than unity, then this group has a higher (lower) marginal impact on productivity than the reference occupation. If all groups have $\theta$ 's equal to one, then Equation (3) becomes $Q L_{i}=$ $L_{i}$, i.e. labour is perfectly homogeneous.

As for the wage equation, Aubert and Crépon (2003) show that the average wage of firm $i$ can be expressed as:

$$
\bar{w}_{i}=\frac{\sum_{j=1}^{G} w_{i, j} L_{i, j}}{\sum_{j=1}^{G} L_{i, j}}=w_{i, 0}\left(\sum_{j=1}^{G} \frac{w_{i, j}}{w_{i, 0}} \frac{L_{i, j}}{L_{i}}\right)=w_{i, 0}\left(1+\sum_{j-\{0\}}^{G}\left(\frac{w_{i, j}}{w_{i, 0}}-1\right) \frac{L_{i, j}}{L_{i}}\right)
$$

where $w_{i, j}$ is the average wage of $L_{i, j}$ and $j=0$ the reference occupation with the wage $w_{i, 0}$. Similar to the interpretation of $\theta$ in the production function, if the ratio $w_{j} / w_{0}$ is bigger (smaller) than unity, then the marginal impact of occupation $j$ on the average wage in the firm is higher (lower) compared to the reference occupation. Comparing marginal productivities and wage differentials across occupations boils down to comparing $\theta_{j}$ with the corresponding $w_{j} / w_{0}$.

\section{Data and Descriptive Statistics}

Our data covers the Belgian labour market and consists of a detailed matched employeremployee panel dataset that combines two complementary sources. The Structure of Earnings Survey (SES), which contains worker-level observations for firms in Belgium within activity sections $\mathrm{C}$ to $\mathrm{K}$ of the NACE nomenclature (Rev.1). This covers the private enterprise sector and excludes agriculture, hunting, forestries and fishing (A and B), public administration (L), 
education (M), health and social security (N), collective, social and personal services (O) and domestic services (P). The SES contains a wealth of information, provided by the management of the firms, both on the characteristics of the latter (e.g. industry, type of financial and economic control, size of the firm) and on their workers (e.g. education, age, seniority, gross hourly wages, bonuses, number of paid working hours, sex, type of employment contract, occupation). Financial information on the same firms covered in the SES are obtained from the Structure of Business Survey (SBS), which provides data on the value added (per hour and per employee) by these firms. The fusion of the SES and SBS datasets has been carried out by Statistics Belgium according to the firm's VAT number. ${ }^{1}$

Two filters have been applied to the original dataset. The first derives its rationale from neoclassical productivity theory, which relies on the assumption that prices are economically meaningful. This is why we deleted firms that are publicly controlled and/or operating in predominantly public sectors from our sample. All regressions are therefore applied to privately controlled firms only. ${ }^{2}$

Second, we have eliminated firms with less than 10 observations, the reason for this being our use of average values at the firm level. In order to assure that averages (like, for instance, the proportion of employees in a specific occupation) are based on a minimum number of observations, we filtered out firms that provided information on less than 10

1 The SES is a stratified sample. The stratification criteria refer respectively to the region (NUTSgroups), the principal economic activity (NACE-groups) and the size of the firm. The sample size in each stratum depends on the size of the firm. Sampling percentages of firms are respectively equal to 10,50 and 100 percent when the number of workers is lower than 50 , between 50 and 99, and above 100 . Within a firm, sampling percentages of employees also depend on size. Sampling percentages of employees reach respectively 100, 50, 25, 14.3 and 10 percent when the number of workers is lower than 20, between 20 and 50, between 50 and 99, between 100 and 199, and between 200 and 299. Firms employing 300 workers or more have to report information for an absolute number of employees. This number ranges between 30 (for firms with between 300 and 349 workers) and 200 (for firms with 12,000 workers or more). To guarantee that firms report information on a representative sample of their workers, they are asked to follow a specific procedure. First, they have to rank their employees in alphabetical order. Next, Statistics Belgium gives them a random letter (e.g. the letter $\mathrm{O}$ ) from which they have to start when reporting information on their employees (following the alphabetical order of workers' names in their list). If they reach the letter $\mathrm{Z}$ and still have to provide information on some of their employees, they have to continue from the letter $\mathrm{A}$ in their list. Moreover, firms that employ different categories of workers, namely managers, blue- and/or white-collar workers, have to set up a separate alphabetical list for each of these categories and to report information on a number of workers in these different groups that is proportional to their share in total firm employment. For example, a firm with 300 employees (namely, 60 managers, 180 white-collar workers and 60 blue-collar workers) will have to report information on 30 workers (namely, 6 managers, 18 white-collar workers and 6 blue-collar workers). For more details see Demunter (2000).

2 We did not eliminate firms for which public financial control does not exceed $50 \%$. The exclusion of these firms would reduce the sample size by less than $4 \%$. 
employees.

In addition to applying these two filters, the final sample on which our estimations are based consists only of firms that are observed in at least three consecutive years due to the inclusion of lagged differences in our models (see Section 5). This leads to a bias towards big firms because of the sample design of the SES in which big firms are more likely to stay in the sample for several consecutive years than small firms.

The three restrictions described above lead to the quasi-suppression of particular activities, for instance in the handicraft sector, but also leads to the fact that certain occupations (like liberal professions: lawyers, medical doctors etc) are under-represented in our data. The final sample consists of an unbalanced panel of 1735 firms yielding 5459 firmyear-observations during the six year period (1999-2006). This panel is representative of all medium-sized and large firms employing at least 10 employees within the sections $\mathrm{C}$ to $\mathrm{K}$ of the NACE 1 (Rev. 1) nomenclature.

The occupational earnings we use in the estimation correspond to the total gross wages, including premia for overtime, weekend or night work, performance bonuses, commissions and other premia. The work hours correspond to the total remunerated hours in the reference period (including paid overtime hours). The firm's value added per hour is measured at factor costs and calculated with the total number of hours effectively worked by the firm's employees. All variables in the SES-SBS are not self-reported by the employees, but provided by the firm's management and therefore more precise compared to employee or household surveys.

The SES-SBS presents occupational data in form of the ILO nomenclature (the International Standard Classification of Occupations). We have estimated added value and wage equations with eight occupational categories for which descriptive statistics are presented in Table 2. An estimation with a more detailed classification including 20 occupations is presented as robustness test in Section 5.3.

\section{[Insert Table 2 here.]}

Although top-earning occupations have high average monthly work hours, it should be noted that these occupations are also relatively high have a bigger share in the total remuneration than in the total hours worked. The category 'Managers', for instance, has a share of $4 \%$ in the total hours worked, but its share in the total remuneration exceeds $8 \%$. By contrast, blue-collar workers have a share in total remuneration that is considerably lower 
than their share in total work hours. For 'Clerical Support Workers', the reference category in our estimations, the shares in remuneration and work hours match each other closely.

Table 3 describes all variables used in our estimations at the firm level. The average values presented here are calculated on the basis of the 5459 observations with which the models in Section 5 have been estimated.

[Insert Table 3 here.]

\section{Specification and Results}

\subsection{Functional Specifications of the Model}

In this section we describe the three different specifications of the Equations (2) and (4) that we estimated. We therefore move from the general form of the added-value and wage equations to a set of functional specifications.

The model formed by Equations (5) and (6) is our baseline specification and similar to the model in Hellerstein et al. (1999). The $\beta_{j}$ in Equation (5) is the relative marginal impact of occupation $j$ (note that $\beta_{j}$ corresponds to $\theta_{j}-1$ in Equation (3)). In Equation (6), $\beta_{j}^{\circ}$ is the relative marginal impact of occupation $j$ on the average wage $\left(\beta_{j}^{\circ}\right.$ corresponds to $w_{j} / w_{0}-1$ in Equation (4)). The terms $\mu_{i, t}$ and $\mu_{i, t}^{\circ}$ represent the error terms.

$$
\begin{aligned}
& \log (\text { VALUEADDED / HOURS })_{i, t}= \\
& \beta_{0}+\sum_{t-\{0\}}^{5} \alpha_{t} I^{t}(\text { YEAR })_{i, t}+\sum_{j-\{0\}}^{7} \beta_{j}\left(\frac{\text { HOURS }}{\text { HOURS }}\right)_{i, t} \\
& +\sum_{k-\{0\}}^{3} \gamma_{k} I^{k}(\text { FIRMAGE })_{i, t}+\sum_{m-\{0\}}^{8} \delta_{m} I^{m}(\text { NACE } 2)_{i, t}+\sum_{s-\{0\}}^{5} v_{s} I^{s}(\text { FIRMSIZE })_{i, t} \\
& +\sum_{e-\{0\}}^{5} \varsigma_{e} E_{\text {EUCATION }}, i, t+\eta \text { WOMEN }_{i, t} \\
& +\sum_{p-\{0\}}^{6} \varphi_{p} \text { AGEGROUPS }_{p, i, t}+\sum_{q-\{0\}}^{2} \lambda_{q} \text { WORKDURATION }_{q, i, t} \\
& +\rho \text { NON }- \text { STANDARDCONTRACT }_{i, t}+\mu_{i, t}
\end{aligned}
$$




$$
\begin{aligned}
& \log (\text { TOTALWAGES / HOURS })_{i, t}= \\
& \beta_{0}^{\circ}+\sum_{t-\{0\}}^{5} \alpha_{t}^{\circ} I^{t}(Y E A R)_{i, t}+\sum_{j-\{0\}}^{7} \beta_{j}^{\circ}\left(\frac{\text { HOURS }_{j}}{\text { HOURS }}\right)_{i, t} \\
& +\sum_{k-\{0\}}^{3} \gamma_{k}^{\circ} I^{k}(\text { FIRMAGE })_{i, t}+\sum_{m-\{0\}}^{8} \delta_{m}^{\circ} I^{m}(\text { NACE } 2)_{i, t}+\sum_{s-\{0\}}^{5} v_{s}^{\circ} I^{s}(\text { FIRMSIZE })_{i, t} \\
& +\sum_{e-\{0\}}^{5} \varsigma_{e}^{\circ} \operatorname{EDUCATION}_{e, i, t}+\eta^{\circ} \text { WOMEN }_{i, t} \\
& +\sum_{p-\{0\}}^{6} \varphi_{p}^{\circ} A_{\text {GEGROUPS }}, i, t+\sum_{q-\{0\}}^{2} \lambda_{q}^{\circ} \text { WORKDURATION }_{q, i, t} \\
& +\rho^{\circ} \mathrm{NON}-\mathrm{STANDARDCONTRACT_{i,t }}+\mu_{i, t}^{\circ}
\end{aligned}
$$

The dependent variable in Equation (5) is the total value added by the firm $i$ in period $t$, divided by the total number of work hours (taking into account paid overtime hours) that have been declared for the same period. The dependent variable in Equation (6) is firm i's average hourly gross wage (including premia for overtime, weekend or night work, performance bonuses, commissions and other premia). It is obtained by dividing the firm's total wage bill by the total number of work hours. Hence, the dependent variables in the estimated equations are firm averages of added-value and wages on an hourly basis. The main independent variables are the shares of hours worked by each occupational category in total work hours, $\left(H O U R S_{j} / H O U R S\right)_{i, t}$. This is a better employment indicator than the number of employees in each category since it takes into account occupational differences in working time.

In addition to the shares of occupations in total work hours, we also included a set of variables controlling for observable characteristics of the firm and its labour force. Since the capital stock of firm $j$ is not available in the SES-SBS, capital is proxied with a dummy variable for nine economic sectors at the one-digit level of the NACE $\left(I^{m}(N A C E 1)_{i, t}\right)$. This is likely to compensate for the omission of capital since the latter tends to be correlated with the type of activity of the firm. Given the results reported in the empirical literature, van Ours and Stoeldraijer (2011) argue that the omission of the exact capital stock does not affect the estimates of production functions on firm-level data since the corresponding productivity effects tend to be small (cf. Hellerstein et al. 1999; Aubert and Crépon, 2003; Dostie, 2011). Additional dummy controls are $I^{k}(\text { FIRMAGE })_{i, t}$, indicating the age of the firm $^{3}$ and

3 Our data set does not provide the firm age directly, which is why we proxied this variable with the seniority of the firm's most senior employee. For the modalities of all variables and the 
$I^{S}(\text { FIRMSIZE })_{i, t}$, the firm's size as measured by the number of employees.

We also control for the composition of the labour force of firm $i: \operatorname{EDUCATION}_{e, i, t}$ are the proportions of educational groups inside the firm; $W O M E N_{i, t}$ is the share of female workers; AGEGROUPS $S_{p, i, t}$ are the proportions of different age groups; $\operatorname{WORKDURATION}_{q, i, t}$ are the shares of part-time and medium-time workers; NON-STANDARDCONTRACT $T_{i, t}$ is the proportion of workers with contracts in which the employment term is not unlimited (for the modalities of all control variables see Table 3). The estimated equations also include the dummy $I^{t}(Y E A R)_{i, t}$ for the year of observation.

We have estimated Equations (5) and (6) with three different methods. The baseline regression is a pooled Ordinary Least Squares (OLS) estimator with robust standard errors (we use a Huber/White/sandwich estimate of variance, i.e. the errors are robust to heteroskedasticity and serial correlation; cf. Wooldridge, 2002). This estimator is based on both the cross-section variability between firms and the longitudinal variability within firms over time.

Our second specification fits a model based on firm averages over time for each variable. This is referred to as the 'between' estimator. In contrast to the pooled OLS estimator, the 'between' regression uses only cross-section variation in the data. The standard errors we report for this estimator are computed with a bootstrap procedure and robust to heteroskedasticity.

Pooled OLS and between estimators of value-added models have been criticized for their potential 'heterogeneity bias' (Aubert and Crépon, 2003; p. 116). This bias is due to the fact that firm productivity depends to some extent on firm-specific, time-invariant characteristics that are not measured in micro-level surveys. As a consequence, the occupational coefficients of these estimators might be biased since unobserved firm characteristics may affect simultaneously the firm's level of added value and its occupational composition. This is referred to as a problem of spurious correlation and could be caused by factors such as an advantageous location, firm-specific assets like the ownership of a patent or other firm idiosyncrasies. One way to deal with unobserved time-invariant heterogeneity of firms is to eliminate firm-level fixed effects by subtracting the corresponding firm-level average from each variable in the model. Hence, our third specification is a fixed-effect specification that uses only longitudinal variation within firms. Since this estimator eliminates firm characteristics that remain unchanged during the observation period, the time-invariant

corresponding descriptive statistics in our sample see Table 3. 
control variables are not included in this specification. Our fixed-effects standard errors are robust to heteroskedasticity and serial correlation (Huber/White/sandwich estimate of variance). We report the Breusch and Pagan Lagrange multiplier to test whether the pooled OLS regression is appropriate and a Hausman specification test to examine whether firmspecific effects are random or fixed.

Estimating Equations (5) and (6) yields insight into the shape and significance of occupational productivity- and wage profiles. We also tested directly whether the difference between the added-value and wage coefficients for a given occupation is statistically significant by estimating a model in which the difference between firm i's hourly added-value and average wage is regressed on the same set of explanatory variables (cf. van Ours and Stoeldraijer, 2011). The resulting occupational coefficients measure directly the size and significance of each occupation's productivity-wage gap.

The reference group in all three estimations is 'Clerical Support Workers', a category that is situated in the centre of the occupational structure with respect to working times and hourly wages (see Table 2). This is a desirable feature for the reference group as it simplifies the interpretation of the relative marginal effects of the other occupational groups.

In addition to pooled OLS, between and fixed-effects (within) estimations, we have carried out a series of robustness tests to examine whether our results are sensitive to (a) the inclusion of dynamics in the model; (b) the way in which we account for unobserved firm heterogeneity; (c) potential endogeneity of the explanatory variables; ; (d) the use of a smaller set of control variables; (e) a more detailed nomenclature of occupations. The outcome of these tests is reported below and shows that the main conclusions presented in the next section are robust to alternative specifications.

\subsection{Estimation Results}

In this section, we first discuss the results for the wages equations and then the value added equations. Afterwards, we compare the coefficients from both equations.

Although the estimated parameters of our control variables are interesting results for their own sake, due to the limited space we do not discuss them in detail. In general, the coefficients of the control variables are often statistically significant (especially in the wage equations) and correspond to the results reported in the literature. For instance, both wages

and value added increase with educational attainment and the age-profile is hump-shaped in the pooled OLS and between estimation (cf. Hægeland and Klette, 1999; Crépon et al., 2002; 
Hellerstein and Neumark, 2007; van Ours and Stoeldraijer, 2011). Furthermore, the estimates indicate that a higher share of women in the firm's workforce has a negative impact on productivity and wages, with respective (statistically significant) OLS coefficients of -0.29 and -0.26 . Compared to the corresponding estimations for other countries, this result points to a somewhat smaller gender effect in Belgium than in Finland, but stronger than in Norway, France and the USA (cf. Ilmakunnas and Maliranta, 2005; pp. 642-643).

\section{[Insert Table 4 here.]}

\subsubsection{Results for Wage Equation}

The most important result with regard to the wage equation is that the parameter estimates are remarkably insensitive to the model specification and reveal a clear pattern of categorical pay differences (see columns 2, 5 and 8 in Table 4). This is an econometric confirmation that occupational categories still play a central role in the determination of earnings at the firmlevel: the distribution of individual wages and salaries is structured by occupational categories. The coefficients of 'Managers' and 'Professionals' are consistently positive and statistical significant in all three models, thereby indicating that these categories have a positive impact on average hourly wage relative to the reference group ('Clerical support workers'). The magnitude of this relationship ranges from 0.35 ('within' estimation) to 0.62 ('between' estimation) for managers, and from 0.09 ('between' estimation) to 0.11 ('within' estimation) for professionals. The other five occupational categories have negative coefficients in all models, which means that these occupations depress the firm's average hourly wage relative to the reference group. The differences between the wage coefficients of the three blue collar categories ('Craft and related trades workers', 'Plant and machine operators and assemblers', 'Elementary occupations') are small but statistically significant in

all estimations. In the pooled OLS regression all occupational coefficients are significant at the five percent level; in the 'between' and 'within' regressions all categories except ‘Technicians and associate professionals’ are significant (see Table 4).

The coefficients of determination show that our model explains more than half of the variation in hourly earnings: $67 \%$ of the overall variation is explained in the OLS regression; $65 \%$ of the inter-firm variation with the between estimator; and $56 \%$ of the intra-firm variation in the fixed-effects regression. All models are statistically significant.

The Breusch and Pagan Lagrange multiplier is 612.34, we therefore refute the null 
hypothesis that pooled OLS is the adequate estimator. This indicates the presence of spurious correlation due to unobservable firm characteristics. The Chi-squared statistic of a Hausman specification test is 493.56 and provides very strong evidence against random and in favour of fixed effects. Although the results are similar across the three specifications, the within estimator is therefore to be preferred over pooled OLS and between regressions.

The wage-occupation profile formed by the estimated coefficients is clearly upwardsloping. To verify whether this profile is statistically significant we have tested whether all occupational coefficients are jointly equal to zero (the p-values of this test are indicated in the row 'Flat profile' in Table 4). The null hypothesis of a flat wage-occupation profile is rejected at the one percent level.

\subsubsection{Results for Productivity Equation}

Turning to the added-value equation, the results reported in Table 4 differ from the wage coefficients. In particular, the estimated (relative) marginal productivities are highly sensitive to the model specification.

The pooled OLS estimates (column 1 in Table 4) display an occupational productivity profile similar to the wage profile. For instance, a higher share of 'Service and Support Workers' not only depresses the firm's average wage, but also average added-value (the statistically significant coefficient is -0.31). Except for 'Professionals', who have negative (relative) marginal productivity but a positive impact on average wages, all other occupational coefficients have the same sign in the OLS added-value and wage equations. The coefficient of determination is 0.27 and we reject the hypothesis of a flat productivity-profile at the one percent level.

The results of the between estimation (column 4 in Table 4) mirror closely the pooled OLS estimator: six of seven between coefficients are significant and have the same sign as the OLS estimates. The coefficient of determination is only slightly smaller $(0.27)$ and we reject a flat productivity-profile.

However, given a Breusch and Pagan Lagrange multiplier of 3870.04, we refute the adequateness of pooled OLS for the estimation of the productivity equation. Since random effects are also rejected with a Hausman statistic of 612.34, the fixed-effects model is again our preferred specification. In contrast to the wage equation, the estimated productivity coefficients change once we account for unobserved firm characteristics via the elimination of time-invariant fixed effects. While the pooled OLS estimator explained $30 \%$ of the overall 
variation and the 'between' estimator $27 \%$ of the inter-firm variation in hourly productivity, the 'within' coefficient of determination plummets to 0.04. Although the 'between' and 'within' coefficients have the same signs, all coefficients but one ('Craft and related trades workers') are statistically insignificant. In addition, we cannot reject the hypothesis of a flat occupational productivity profile after eliminating fixed effects.

\subsubsection{Comparison of Coefficients from Productivity and Wage Equations}

In order to test whether an occupation's impact on the firm's wage level matches its marginal productivity, we have estimated productivity-wage gaps by regressing the difference between firm i's hourly added-value and average wage on the same set of explanatory variables we used previously. A negative gap is interpreted as over- and a positive gap as underpayment with respect to productivity. The results are also reported in Table 4 (columns 3, 6 and 9).

With pooled OLS, all gaps are negative but only 'Professionals' and 'Craft and related trades workers' appear to be significantly overpaid. The between estimator produces the same pattern except that the negative gap for 'Technicians and associate professionals' also become significant at the ten percent level. However, the outcome of the Lagrange multiplier and Hausman tests reported above indicates these results are strongly biased due to the existence of firm-level fixed effects.

The within estimator reveals a clear pattern of significant over- and underpayment. The occupations at the top of the wage hierarchy ('Managers' and 'Professionals') appear to be overpaid, the highly significant productivity-wage gaps being -0.31 and -0.12 , respectively. 'Service and Sales workers' as well as all blue-collar occupations come out as being significantly underpaid with respect to their relative marginal productivities.

\subsection{Robustness Tests}

We carried out several tests to assess the robustness of the results presented in the previous section. The main results stand up to a range of alternative model specifications.

\subsubsection{Static versus Dynamic Specification}

A dynamic version of the pooled OLS and within estimator has been computed by including a one-period lag of the dependant variable among the regressors. In other words, we allow for 
added-value to be not only related to contemporary inputs, but also to be a function of addedvalue in previous periods (Arellano and Bond, 1991; Göbel and Zwick, 2009). The lagged dependant variable is found to be highly significant in both equations and reduces the significance of the occupational coefficients in the productivity equations even further than in the static specification (see Table A.1). The overall explanatory power of the added-value models is considerably higher compared to the static specification, indicating the existence of a dynamic component in firm production.

While a flat productivity profile is rejected in the dynamic OLS regression with a pvalue of 0.08 , no significant differences in occupational productivity can be detected with fixed effects. This confirms our previous results. Furthermore, the significant and upwardsloping occupation-wage profile revealed by the static model is also robust to the alternative specification, even though almost all wage coefficients are somewhat smaller in the dynamic than in the static version. Table A.1 also reports the gaps between the coefficients of addedvalue and wage equations. The productivity-wage gaps in the dynamic fixed-effects specification are almost identical compared to the model without lagged dependent variable (column 9 in Table 4). We conclude that the pattern of over- and underpayment is very similar in the dynamic and static specifications.

\subsubsection{Alternative Procedure to Account for Unobserved Heterogeneity}

Our baseline model accounts for unobserved heterogeneity between firms by subtracting the firm average from each variable in the model. An alternative strategy is to take first differences of all variables (cf. Aubert and Crépon, 2003). First differences do not estimate the level of productivity of firm $i$, but the change in productivity. Time-invariant heterogeneity is by definition not linked to changes in productivity and therefore controlled for. We have estimated the dynamic added-value and wage equations in first differences with robust standard errors (columns 1 and 2 in Table A.2). The results are similar to our preferred fixedeffects estimation: all wage coefficients are individually and jointly significantly different from zero, while the hypothesis of a flat productivity-profile cannot be rejected. The productivity-wage gaps display the same pattern as with fixed effects and all gaps are statistically significant (column 3 in Table A.2). We therefore conclude that whether unobserved heterogeneity is accounted for by taking first-differences or including firmspecific fixed effects does not affect our conclusions. 


\subsubsection{Changes in Occupational Shares May Need Time to Affect Productivity}

The observed contrast between productivity and wage equations could reflect that the dynamics of changes in a firm's occupational composition work differently for productivity than for wages. Imagine, for instance, that a firm replaces certain tasks previously carried out by traditional secretaries with IT-based solutions. This may lead to an immediate decrease in the share of secretarial staff and an increase of technicians and programmers in the total hours worked within the firm. As a consequence, the average wage of the firm will also change immediately. However, the effect on the firm's value added may not be visible until the entire personnel has learned to work with the new technology. Typically, certain tasks performed by secretaries and technicians will overlap during a transition period, thereby affecting negatively the observed productivity of both groups. The idea that changes need more time to affect productivity than wages - i.e. productivity might be stickier than wages - could also explain why we observe a significant occupation-productivity profile in the between regression. This estimator uses only cross-section variation in productivity and occupational compositions. Since differences in the occupational composition between firms are the cumulative result of past changes, the between estimator might capture the impact of occupations on productivity after the former had sufficient time to develop an effect on the latter.

To investigate the incidence of this phenomena on our results, we estimated alternative specifications of the baseline model that allow for a delayed impact of changes in occupational shares on productivity. First, we tested whether the productivity coefficients are affected if we use longer differences instead of the year-to-year changes presented in the previous section. For instance, columns 4 to 6 in Table A.2 are based on differences over two years (i.e. between $t$ and $t$-2). In this regression the wage coefficients remain almost unchanged, although the coefficient of determination of the model decreases somewhat compared to the first-differenced specification. The productivity coefficients in the model with longer differences remain insignificantly different from the reference occupation, and we cannot reject the hypothesis of a flat productivity profile (the p-value is 0.61). Very similar results are obtained in a model based on changes over three years: here, the p-value for the flat productivity profile is 0.34 and the negative productivity-wage gaps for Managers and Professionals remain significant (all results cannot be reported here due to space constraints).

Second, we estimated specifications of our model in which the changes in firm productivity are regressed on lagged changes in the occupational shares, e.g. by regressing the 
change in the dependent variable between $t$ and $t-1$ on the change in the independent variables between $t-2$ and $t-3$. We not only experimented with models in which lagged differences are based on year-to-year changes, but also with lagged differences over two and three years (i.e. changes in productivity between $t$ and $t-2$ are fitted on changes in the occupational shares between $t-3$ and $t-5)$. In none of the differenced models we can reject the hypothesis that the productivity differentials are jointly equal to zero. This means that we cannot find evidence for productivity differentials between occupations even if we allow for the productivity impact of changes in a firm's occupational composition to occur after a transition period of several years.

\subsubsection{Potential Endogeneity of Occupational Shares}

The fourth robustness test addresses the potential bias caused by simultaneity, a problem that has received considerable attention in productivity estimations (Marshak and Andrews, 1944; Griliches and Mairesse, 1998). At stake is the potential correlation of the explanatory variables with the error term. This situation can arise when firms anticipate exogenous shocks. For instance, if a firm in period $t$ anticipates an increase in demand in period $t+1$, it may adjust its labour mix by already hiring more workers in period $t$. This could increase the proportion of occupations that can be hired and fired more easily. As a consequence, measured productivity and the proportion of these occupations would increase simultaneously in period $t$ and lead to biased estimations of the corresponding parameters. A way to address the simultaneity problem is to use instruments that are correlated with the problematic explanatory variables and uncorrelated with the exogenous shocks (i.e. the error term).

To explore the acuteness of the simultaneity problem in our data, we have estimated two models with instrumental variables. First, we have estimated a dynamic model in firstdifferences and instrumented the (differenced) occupational shares with the one-period lag of the level of these shares (see columns 4 and 5 in Table A.2). In other words, the lagged level of occupational shares is assumed to be correlated with future values of the instrumented variables but not with the exogenous shocks. ${ }^{4}$ We estimated the IV first-differenced equations using the Generalized Method of Moments (GMM) with a Newey-West variance-covariance matrix and standard errors that are robust to heteroskedasticity and serial correlation. This IV

4 We have experimented with a larger set of instruments, for instance by including lags of occupational shares for $t-2$ and $t-3$. However, only the smaller set including only one-period lags passed the test of weak identification. 
approach has been applied to productivity and wage equations by Aubert and Crépon (2003) and is now standard in the literature (cf. van Ours, 2009; Göbel and Zwick, 2009). Second, we have used IV to examine the simultaneity problem in the fixed-effects specification. While we have used (one-period lags) of levels of occupational shares to instrument the equation in first differences, we employ first differences of occupational shares to instrument the fixed-effects equation in levels (see Arrelano and Bover, 1995; Crépon et al., 2002).

For both estimations we have computed the standard diagnostic tests for instrumental variables. First, the Kleibergen-Paap statistic for underidentification tests whether the equation is identified, i.e. whether the excluded instruments are all relevant. The null hypothesis in this test is that the equation is underidentified. Second, the Kleibergen-Paap statistic for weak identification is a Wald F statistic testing whether the excluded instruments are sufficiently correlated with the endogenous regressors (the null hypothesis being weak identification). Since a rejection rule for this test has yet to be established, we rely on the 'rule of thumb ' that weak identification is problematic for F-statistics smaller than 10 (cf. van Ours and Stoeldraijer, 2011). Finally, we compute an endogeneity test with the null hypothesis that the occupational shares can actually be treated as exogenous. The test is based on the difference of two Sargan-Hansen statistics: one for the equation in which the occupational shares are treated as endogenous, and one in which they are treated as exogenous. If the null hypothesis of this test cannot be rejected, then instrumentation is actually not necessary.

The results in Table A.2 indicate that under- and weak identification is unproblematic in our case: we reject the hypothesis of underidentification in both the GMM-IV and the instrumented equation with fixed effects at the one percent level; the Kleibergen-Paap statistics for weak identification are above 10 for both GMM-IV and fixed effects. However, we cannot reject the hypothesis that the occupational shares can actually be treated as exogenous: the corresponding p-values are 0.47 (added-value) and 0.57 (wage) in the firstdifferenced GMM, and 0.35 (added-value) 0.59 (wage) with fixed effects. This means that instrumentation is actually not necessary since there appears to be no endogeneity in the occupational shares once we control for time-invariant, unobserved firm characteristics by either taking first differences or fixed effects. The simultaneity bias that has been diagnosed in other empirical studies is therefore negligible in our case. This may be an indication that simultaneity affects the age structure - which is the main explanatory variables in the IV regressions by Aubert and Crépon (2003) and van Ours and Stoeldraijer (2011) - more than the occupational composition of firms.

The results for GMM-IV reported in Table A.2 should therefore be read with the 
disclaimer that the IV estimates are less efficient compared to our baseline model with fixed effects and that instrumentation is actually not necessary in our case. This being said, the GMM-IV estimation leads again to a flat productivity profile and a significant wage profile of similar magnitude and sign compared to our preferred specification. Furthermore, we observe the same pattern of productivity-wage gaps, although the higher standard errors caused by the instrumentation create the impression that only the productivity-wage gaps at the bottom of the occupational hierarchy are statistically significant.

\subsubsection{Specification without Worker Controls}

Our baseline specification controls for the composition of the firm's labour force in terms of educational attainment, gender ratio, age groups, the extent of medium- and part-time work and the proportion of non-standard work contracts. This is the standard procedure to create a ceteris paribus effect for the occupation variable. An alternative perspective on our question can be obtained by regressing productivity and wage equations on occupational categories without the control variables in the model. In this case, an occupation's composition in terms of age or education is viewed as a constituent element of its impact on productivity and wages instead of isolating the occupational coefficients from these characteristics.

We have computed the dynamic pooled OLS and within estimators excluding worker controls and find our conclusions unaltered. Without controls, the magnitude of the wage coefficients in the fixed-effects regression further increases while the productivity coefficients are hardly modified. Occupations are affected asymmetrically by the exclusion of worker controls, with the increase of coefficients at the top being stronger than the decrease at the bottom of the hierarchy: for instance, the wage coefficient of 'Managers' changes from 0.34 to 0.48, while 'Elementary occupations' decrease from -0.24 to -0.29 . As a consequence, the productivity-wage gaps widen and remain significant if we exclude the control variables (the estimation results can be obtained from the authors but are not reported here due to space restrictions). Again, we cannot reject a flat productivity profile (p-value $=0.64$ ) while the wage coefficients are individually and jointly significantly different from zero (p-value = $0.00)$.

\subsubsection{Specification with Detailed Occupational Nomenclature}

Finally, we have tested whether an alternative classification of occupations alters the 
statistical relationships between occupations and added-value/wages. The intuition behind the test is that the strength of this relationship depends on the scope of occupational categories. If the categories are too encompassing, they might mask productivity and wage differences. On the other hand, more detailed categories also lead to fewer observations per firm and therefore a set of independent variables with a lower degree of precision. We have estimated our three baseline models employing a more detailed nomenclature including 20 occupations (due to space restrictions the results are not reported here). Again, we observe no substantial deviation from the baseline results. We cannot reject a flat productivity profile in the model that accounts for unobserved heterogeneity (p-value $=0.70)$ and the occupational wage profile has the familiar shape with almost all coefficients being positive above and negative below the reference occupation ('Customer services clerks'). Most of the wage coefficients are statistically significant and we reject the hypothesis of a flat profile. In the 'within' estimation, the productivity-wage gaps tend to be negative at the top of the hierarchy (indicating overpayment with respect to productivity) and positive at the bottom (indicating underpayment).

\section{Discussion}

We observe a contrast between the productivity and wage equation: while the elimination of firm-level fixed effects leads to a break-down of the statistical relationship between occupational composition and productivity, changes in occupations still explain more than half of the intra-firm variation in hourly wages and we observe a clear and significant occupation-wage profile. Three alternative interpretations of this phenomena can be envisaged.

First, the insignificant productivity differences between occupational categories in the within regression could be due to the variability of the independent variables. If the dispersion of the occupational shares is lower within firms over time than between firms, then this could lead to weaker (i.e. less efficient) statistical relationships between dependent and independent variables. As reported in Table A.3, the variation of all occupational shares is indeed lower in the within dimension, resulting in less efficient estimators with fixed effects compared to the between estimator. However, this holds for both productivity and wage equations and therefore cannot explain the difference between the two. In other words, the variation of occupational shares is indeed lower within than between firms, but the same level of intrafirm dispersion produces simultaneously an upward-sloping wage- and a flat productivity- 
profile. Hence, while the higher cross-section variation in the occupational composition explains the loss of efficiency when passing from the between to the fixed-effects estimator, it cannot account for the fact that this loss is considerably higher in the productivity than in the wage equation.

Second, the flatness of the productivity profile and the pattern of productivity-wage gaps could be the result of noise in the hours measure. In fact, it is plausible that working hours reported by high-paid occupations ('Managers', 'Professionals') underestimate actual hours since the working time in these occupations tends to be less regulated and often exceeds the reference hours fixed in employment contracts. This measurement error could lead to an underestimation of the productivity- and an overestimation of the wage-impact of these occupations. As a consequence, not only the insignificant productivity differences with respect to the reference category, but also the significant productivity-wage gaps we observe at the top of firm hierarchies might to some extent be due to underestimated working hours. This, however, can only be a partial explanation of our results. Even if the measured productivity-wage gap of 'Managers' probably exaggerates the overpayment of this category (-0.31 in our preferred model), it is unlikely that the underestimation of hours accounts for the entire gaps of all categories. In particular, although the actual working hours of lower white collar and the blue collar occupations are typically close to contractual working time, we still find insignificant productivity differences and significant underpayment for these categories.

The third and most obvious explanation for the difference in explanatory power between productivity and wage equations is the elimination of spurious correlation through the introduction of firm-level fixed effects. In other words, the strong impact of the occupational composition on firm production in the 'between' estimation is to some extent due to a bias: once we control for the numerous unobserved time-invariant differences between firms, no economy-wide occupation-productivity profile can be detected. The fact that the wage coefficients and their significance remain stable when moving from the between to the within estimator suggests that the heterogeneity bias is more pronounced in the productivity than in the wage equation.

A flat occupation-productivity profile is a surprising result in light of the standard hypothesis of wages being equal to productivity, but it actually echoes empirical findings of other authors who estimated marginal productivities for different groups of workers with fixed-effects regressions. Ilmakunnas and Maliranta (2005), interested in the effects of age, education and gender in Finland, obtain highly significant relative marginal productivities under pooled OLS, but only three of their six education parameters remain significant when 
fixed effects are eliminated. In addition, all coefficients for education have the wrong sign in their fixed-effects regression. ${ }^{5}$ In a similar OLS regression of added-value in Germany, almost all age, education and occupation coefficients are found to be significant (Göbel and Zwick, 2009). However, in the specification with fixed effects only gender and nationality appear to have a significant impact on productivity. Another related study is van Ours and Stoeldraijer (2011), who examine the impact of a firm's age composition on added-value in the Netherlands. Instead of using a fixed-effects estimator, they take unobserved firm heterogeneity into account by applying first differences. While all pooled OLS coefficients in their productivity equation are significant, their estimates in first differences are all insignificantly different from the reference group and indicate a flat productivity profile.

How do our econometric results compare with the theoretical literature on productivity-wage gaps? A compressed occupational wage distribution relative to the distribution of marginal productivities would lead to positive differences at the top and negative differences at the bottom of the occupational hierarchy. None of our estimators displays such a pattern. The productivity-wage gaps in our preferred specification (column 9 in Table 4) displays a clear pattern of significant overpayment at the top ('Managers', 'Professionals'), and underpayment at the bottom of the occupational hierarchy ('Service and sales workers', 'Craft and related trades workers', 'Plant and machine operators', 'Elementary occupations'). Hence, our results speak against theories predicting a compressed wage distribution. If it is true that quasi-fixed costs and firm-specific skills are higher at the top of the occupational hierarchy than at the bottom, this appears not to be the main determinant of occupational pay rules. The prediction of the theory of interdependent preferences cannot be confirmed either: there appears to be no trade-off between a relatively high status and relatively high wages at the occupational level. We find no evidence that high-status occupations like 'Managers' and 'Professionals' are underpaid, and low-status occupations appear to be rather under- than overpaid in our preferred specification. Similarly, the observed pattern of occupational productivity-wage differences does not corroborate the theory according to which gaps arise from slow adjustments of 'social norms' (or the firm's 'customs') to changes in occupational productivity. Since recent technological changes are typically assumed to have decreased the relative productivity of low-skilled occupations in the lower part of the occupational hierarchy, we would expect these occupations to be overpaid

5 In their fixed-effects regression all education coefficients are negative. Since the reference group is the lowest educational level (comprehensive schooling), this would mean than any additional schooling beyond comprehensive education leads to lower productivity (Ilmakunnas and Maliranta, 2005; p. 637, Table 3). 
due to the inertia of wage norms. Again, the observed pattern of productivity-wage gaps provides no evidence for this hypothesis.

Our findings are easier to reconcile with the set of theories that predict upward (downward) deviations from marginal productivity at the top (bottom) of the occupational hierarchy. This includes the structure of occupational overpayment implied by tournament theory, certain institutional approaches to intra-firm relations and closure theory. For instance, we could interpret the overpayment of white-collar occupations as the result of the appropriation of rent generated by the firm. This could reflect that 'Managers' and 'Professionals' have typically better access to firm-related information and a more prominent position in the firm's hierarchy of authority and control as compared to blue-collar occupations. Closure theory offers a complementary interpretation: the observed pattern of productivity-wage gaps do not contradict the hypothesis that the occupations with high remuneration are those that are more successful in closing off their positions against competition. For instance, access to the categories 'Managers' and 'Professionals' is typically regulated on the basis of scarce educational credentials that could be unrelated to higher productivity (cf. Duru-Bellat, 2006).

\section{Conclusion}

Theories on the determination of occupational earnings typically make reference to productivity differences between occupations. This does not only hold for the human capital model: the literatures on the impact of incentive problems (Lazear and Shaw, 2007) or institutional factors (Osterman et al., 2009) on wages also formulate arguments in terms of productivity by predicting deviations from productivity-based pay, be they a compressed or a wider earnings distribution compared to occupational productivity. Unfortunately, the wealth of theoretical work on occupational earnings is not matched by a corresponding body of empirical literature so that Gottschalk's (1978) finding of occupational productivity being inversely related to earnings still stands unrefuted. In this paper we have used a matched employer-employee dataset to explore to what extent wages and salaries paid to occupational categories correspond to their respective marginal productivities.

Our econometric results confirm that occupations still play a central role in the determination of earnings. The estimations reveal an upward-sloping and significant occupational wage profile that is insensitive to the model specification and a series of robustness tests. By contrast, the evidence for a corresponding productivity profile in which 
the higher-paid occupations also add more value is much thinner. While such a profile is suggested by a pooled OLS model, we conclude that pooled results are biased due to spurious correlation between the level of value added and the firm's occupational composition, a bias that could be caused by unobservable firm characteristics. No clear productivity profile is found once we eliminate time-invariant idiosyncrasies (either through fixed effects or differenced equations). As a consequence, the hypothesis of a flat productivity profile cannot be rejected in our preferred specification. While this result is surprising in light of the classical hypothesis of productivity being the main determinant of occupational earnings, previous empirical studies with similar methodologies also reported insignificant productivity differences between employees when the latter are stratified by educational attainment or age groups.

Insignificant productivity differences between occupations can of course be attributed to the notorious imprecision of added-value equations, but this imprecision merely unveils a substantial variation in the occupation-productivity profiles among firms. One way to interpret our results is to see the absence of systematic productivity differences between occupations as a result of changes in production processes: the more complex, specialised and idiosyncratic firm-level value creation becomes, the more difficult it is to identify systematic productivity differences between occupations for the economy as a whole. What is striking is that firm-level idiosyncrasies in occupational productivity have apparently not affected the wide-spread use of occupational categories in decisions on employee remuneration.

Combined with an upward-sloping occupational wage profile, the absence of significant productivity differences between occupations suggests that occupations at the top of the wage hierarchy are overpaid with respect to their marginal productivity and occupations at the bottom underpaid. This finding confirms Gottschalk's results from the late 1970s and indicates the importance of alternative theories beside marginal productivity for our understanding of occupational pay differences. In this sense, the findings presented in this paper lend econometric backing for Max Weber's warning that 'the 'law of marginal productivity’ also holds for 'marginal productivity theory’ ’(Weber, 1991 [1904]).

\section{References}

Acemoglu, D. (2002). 'Technical change, inequality, and the labor market. Journal of Economic Literature, 40, 7-72.

Acemoglu, D., \& Pischke, J.-S. (1999). The structure of wages and investment in general 
training, Journal of Political Economy, 107, 539-572.

Arellano, M., \& Bond, S. (1991). Some tests of specification for panel data: Monte Carlo evidence and an application to employment equations, Review of Economic Studies, 58, 277-297.

Arellano, M., \& Bover, O. (1995). Another look at the instrumental variables estimation of error-components models, Journal of Econometrics, 68, 29-51.

Aubert, P., \& Crépon, B. (2003). Age, salaire et productivité: La productivité des salariés décline-t-elle en fin de carrière? Economie et statistique, 368, 95-119.

Autor, D.., Katz, L., \& Krueger, A. (1998). Computing inequality: Have computers changed the labor market? Quarterly Journal of Economics, 113, 1169-1213.

Bebchuk, L., \& Fried, J. (2003). Executive compensation as an agency problem, Journal of Economic Perspectives, 17, 71-92.

Berg, Ivar E (1981). Sociological perspectives on labor markets. Academic Press.

Cardoso, A., Guimarães, P., \& Varejão, J. (2011). Are older workers worthy of their pay? An empirical investigation of age-productivity and age-wage nexuses. De Economist, 159, 95111.

Cataldi, A., Kampelmann, S., \& Rycx, F. (2011). Productivity-wage gaps among age groups: Does the ICT environment matter? De Economist, 159, 193-221.

Crépon, B., Deniau, N., \& Pérez-Duarte, S. (2002). Wages, productivity, and worker characteristics: A French perspective. CREST working paper.

Demunter, C. (2000). Structure and distribution of earnings survey: Analysis 1995. Statistics Belgium working paper.

Doeringer, P., \& Piore, M. (1985). Internal labor markets and manpower analysis. ME Sharpe.

Dostie, B. (2011). Wages, productivity and aging. De Economist, 159, 139-158.

Duru-Bellat, M. (2006). L'inflation scolaire. Les désillusions de la méritocratie. Paris: Editions du Seuil et la République des Idées.

Frank, R. (1984). Are workers paid their marginal products? American Economic Review, 74, 549-571.

Göbel, C., \& Zwick, T. (2009). Age and productivity: Evidence from linked employer employee data. ZEW discussion paper nr. 09-020.

Gottschalk, P. (1978). A comparison of marginal productivity and earnings by occupation. Industrial and Labor Relations Review, 31, 368-378.

Gottschalk, P., \& Tinbergen, J. (1982). Methodological issues in testing the marginal 
productivity theory, De Economist, 130, 325-335.

Griliches, Z., \& Mairesse, J. (1998). Production functions: The search for identification, in Econometrics and economic theory in the twentieth century: The Ragnar Frisch Centennial Symposium, ed. by Strøm, S. Cambridge, U.K.: Cambridge University Press, 169-203.

Hægeland, T., \& Klette, T. (1999). Do higher wages reflect higher productivity? Education, gender and experience premiums in a matched plant-worker data set, in The creation and analysis of employer-employee matched data, ed. by Haltiwanger, J., Lane, J., Spletzer, J., Theeuwes, J., \& Troske, K. Amsterdam: North-Holland.

Hamermesh, D. (1975). Interdependence in the labour market. Economica, 42, 420-429.

Hellerstein, J., Neumark, D., \& Troske, K. (1999). Wages, productivity, and worker characteristics: Evidence from plant-level production functions and wage equations. Journal of Labor Economics, 17, 409-446.

Hellerstein, J., \& Neumark, D. (2007). Production function and wage equation estimation with heterogeneous labor. Evidence from a new matched employer-employee data set, in Hard-to-measure goods and services: Essays in honor of Zvi Griliches, ed. by Berndt, E., \& Hulten, C. Chicago: University of Chicago Press.

Ilmakunnas, P., \& Ilmakunnas, S. (2011). Divesrity at the workplace: Whom does it benefit? De Economist, 159, 223-255.

Ilmakunnas, P., \& Maliranta, M. (2005). Technology, labour characteristics and wageproductivity gaps. Oxford Bulletin of Economics and Statistics, 67, 623-645.

Kalleberg, A., \& Sørensen, A. (1979). The sociology of labor markets. Annual Review of Sociology, 5, 351-379.

Lazear, E., \& Rosen, S. (1981). Rank-order tournaments as optimum labor contracts. Journal of Political Economy, 89, 841-864.

Lazear, E., \& Shaw, K. (2007). Personnel economics: The economist's view of human resources. Journal of Economic Perspectives, 21, 91-114.

Levine, D. (1991). Cohesiveness, productivity, and wage dispersion. Journal of Economic Behavior \& Organization, 15, 237-255.

Marshak, J., \& Andrews, W. (1944). Random simultaneous equations and the theory of production. Econometrica, 12, 143-205.

Mincer, J. (1958). Investment in human capital and personal income distribution. Journal of Political Economy, 66, 281-302.

Mincer, J. (1970). The distribution of labour incomes: A survey with special reference to the 
human capital approach. Journal of Economic Literature, 8, 1-26.

Müller, H.-P., \& Schmid, M. (2003). Hauptwerke der ungleichheitsforschung. Westdeutscher Verlag.

OI, W. (1962). Labor as a quasi-fixed factor. Journal of Political Economy, 70, 538-555.

Osterman, P., Auer, P., Gautié, J., \& Marsden, D. (2009). Discussion: A new labour economics? Socio-Economic Review, 7, 695-726.

Scully, G. (1974). Pay and performance in major league baseball. American Economic Review, 64, 915-930.

Skott, P. (2005). Fairness as a source of hysteresis in employment and relative wages. Journal of Economic Behavior \& Organization, 57, 305-331.

Sørensen, A. (1996). The structural basis of social inequality. American Journal of Sociology, 101, 1333-1365.

Sørensen, A. (2000). Toward a sounder basis for class analysis. American Journal of Sociology, 105, 1523-1558.

Vandenberghe, V. (2011a). Boosting the employment rate of older men and women.An empirical assessment using Belgian firm-level data on productivity and labour costs. De Economist, 159, 159-191.

Vandenberghe, V. (2011). Firm-level evidence on gender wage discrimination in the Belgian private sector. Labour, forthcoming.

van Ours, J. (2009). Will you still need me - When I'm 64? De Economist, 157, 441-460.

van Ours, J., \& Stoeldraijer, L. (2011). Age, wage and productivity in Dutch manufacturing. De Economist, 159, 113-137.

Weber, M. (1991 [1904]). Die 'objektivität' sozialwissenschaftlicher und sozialpolitischer erkenntnis. P. Reclam jun (Schriften zur Wissenschaftslehre).

Weeden, K. (2002). Why do some occupations pay more than others? Social closure and earnings inequality in the United States. American Journal of Sociology, 108, 55-101.

Wooldridge, J. (2002). Econometric analysis of cross section and panel data. Cambridge, MA: MIT Press. 
Tab. 1: Comparison of median earnings and marginal revenue products (in US dollars).

\begin{tabular}{lccc}
\hline Occupation & Median earnings & $\begin{array}{c}\text { Marginal Revenue } \\
\text { Product }\end{array}$ & Discrepancy ratio \\
\hline Managers & 8,189 & 4,035 & 2.03 \\
Sales & 6,136 & 2,324 & 2.64 \\
Professionals & 6,007 & 5,343 & 1.12 \\
Craftsmen & 4,875 & 13,942 & 0.35 \\
Operations & 3,797 & 8,598 & 0.44 \\
Clerical & 3,640 & 5,804 & 0.63 \\
Labourers & 3,154 & 5,804 & 0.54 \\
Service & 2,871 & 5,804 & 0.49 \\
\hline
\end{tabular}

Source: Gottschalk (1978, p. 375).

Tab. 2: Descriptive statistics for occupations.

\begin{tabular}{lccccccc}
\hline & $\begin{array}{l}\text { Share in } \\
\text { total hours } \\
\text { worked }\end{array}$ & $\begin{array}{l}\text { Share in } \\
\text { total } \\
\text { wages }\end{array}$ & $\begin{array}{l}\text { Average } \\
\text { monthly } \\
\text { hours }\end{array}$ & $\begin{array}{l}\text { Average } \\
\text { hourly } \\
\text { wage }\end{array}$ & $\begin{array}{l}\text { Median } \\
\text { hourly } \\
\text { wage }\end{array}$ & $\begin{array}{l}\text { IQR } \\
\text { hourly } \\
\text { wage }\end{array}$ & $\begin{array}{l}\text { S.D. } \\
\text { Hourly } \\
\text { wage }\end{array}$ \\
\hline $\begin{array}{l}\text { Managers } \\
\text { Professionals }\end{array}$ & 0.04 & 0.09 & 163.5 & 34.0 & 28.9 & 19.1 & 21.2 \\
$\begin{array}{l}\text { Technicians and associate } \\
\text { professionals }\end{array}$ & 0.12 & 0.18 & 163.3 & 23.2 & 20.9 & 10.9 & 12.1 \\
Clerical support workers & 0.09 & 0.11 & 160.1 & 18.0 & 16.4 & 7.6 & 7.1 \\
Service and sales workers & 0.21 & 0.20 & 151.3 & 15.4 & 14.3 & 5.9 & 6.1 \\
Craft and related trades workers & 0.07 & 0.05 & 123.6 & 11.8 & 10.3 & 4.1 & 9.2 \\
$\begin{array}{l}\text { Plant and machine operators, } \\
\text { and assemblers }\end{array}$ & 0.21 & 0.17 & 148.0 & 12.5 & 12.3 & 2.6 & 3.2 \\
Elementary occupations & 0.17 & 0.14 & 158.9 & 12.6 & 11.9 & 3.9 & 4.3 \\
\hline Total & 0.08 & 0.06 & 130.4 & 11.3 & 10.7 & 2.8 & 4.8 \\
\hline Average & 1 & 1 & 148.0 & 14.9 & 12.8 & 5.6 & 8.9 \\
\hline
\end{tabular}

Average values for 1999-2006; wages in 2004 Euros (deflated with Consumer Price Index). IQR is the interquartile range: $\mathrm{w}(\mathrm{Q} 75)-\mathrm{w}(\mathrm{Q} 25)$. 
Tab. 3: Descriptive statistics for firms (1999-2006).

\begin{tabular}{|c|c|c|}
\hline & Mean & $\begin{array}{l}\text { Standard } \\
\text { deviation }\end{array}$ \\
\hline Added value per hour (2004 Euros) & 55.5 & 207.2 \\
\hline Hourly wage (2004 Euros) & 17.2 & 4.8 \\
\hline Monthly working hours & $6,510.3$ & $7,909.4$ \\
\hline \multicolumn{3}{|l|}{ Firm age } \\
\hline$<1$ years & 0 & \\
\hline 2 to 4 years & 0.01 & \\
\hline 5 to 9 years & 0.05 & \\
\hline$>10$ years & 0.93 & \\
\hline \multicolumn{3}{|l|}{ Number of employees per firm } \\
\hline$<19$ & 0.01 & \\
\hline 20 to 49 & 0.03 & \\
\hline 50 to 99 & 0.08 & \\
\hline 100 to 199 & 0.18 & \\
\hline 200 to 499 & 0.44 & \\
\hline$>500$ & 0.27 & \\
\hline \multicolumn{3}{|l|}{ Educational composition of work force } \\
\hline Lower Education & 0.08 & 0.16 \\
\hline Lower Secondary Education & 0.26 & 0.27 \\
\hline General Upper Secondary School & 0.18 & 0.22 \\
\hline Technical/Artistic/Professional Upper Secondary School & 0.22 & 0.24 \\
\hline Short Higher Education & 0.16 & 0.16 \\
\hline Long Higher Education or University & 0.11 & 0.14 \\
\hline Share of female workers & 0.25 & 0.22 \\
\hline \multicolumn{3}{|l|}{ Age composition of work force } \\
\hline$<19$ years & 0.01 & 0.02 \\
\hline 20 to 24 years & 0.07 & 0.07 \\
\hline 25 to 29 years & 0.14 & 0.09 \\
\hline 30 to 34 years & 0.16 & 0.09 \\
\hline 35 to 44 years & 0.33 & 0.11 \\
\hline 45 to 59 years & 0.29 & 0.15 \\
\hline$>60$ years & 0.01 & 0.02 \\
\hline \multicolumn{3}{|l|}{ Conventional work hours } \\
\hline Part time (<20 work hours per week) & 0.02 & 0.08 \\
\hline Medium time (20 to 38 work hours p.w.) & 0.34 & 0.39 \\
\hline Full time (> 38 work hours p.w.) & 0.64 & 0.41 \\
\hline Non standard work contracts* & 0.04 & 0.1 \\
\hline Number of firms in the sample & 1,735 & \\
\hline Number of observations & 5,459 & \\
\hline
\end{tabular}

*Non standard work contracts include all contracts without an unlimited term. 
Tab. 4: Estimation results.

\begin{tabular}{|c|c|c|c|c|c|c|c|c|c|}
\hline & \multicolumn{3}{|c|}{ Pooled OLS } & \multicolumn{3}{|c|}{ Between } & \multicolumn{3}{|c|}{ Fixed effects (within) } \\
\hline & $\begin{array}{c}1 \\
\text { value added }\end{array}$ & $\begin{array}{c}2 \\
\text { wage }\end{array}$ & $\begin{array}{c}3 \\
\text { gap }\end{array}$ & $\begin{array}{c}4 \\
\text { value added }\end{array}$ & $\begin{array}{c}5 \\
\text { wage }\end{array}$ & 6 & $\begin{array}{c}7 \\
\text { value } \\
\text { added }\end{array}$ & $\begin{array}{c}8 \\
\text { wage }\end{array}$ & $\begin{array}{l}9 \\
g a p\end{array}$ \\
\hline Managers & $\begin{array}{c}0.28 \\
(0.17)\end{array}$ & $\begin{array}{c}0.46^{* * * *} \\
(0.05)\end{array}$ & $\begin{array}{l}-0.18 \\
(0.16)\end{array}$ & $\begin{array}{c}0.45 \\
(0.31)\end{array}$ & $\begin{array}{c}0.62 * * * \\
(0.09)\end{array}$ & $\begin{array}{l}-0.17 \\
(0.27)\end{array}$ & $\begin{array}{c}0.04 \\
(0.09)\end{array}$ & $\begin{array}{c}0.35^{* * *} \\
(0.05)\end{array}$ & $\begin{array}{c}-0.31^{* * *} \\
(0.10)\end{array}$ \\
\hline Professionals & $\begin{array}{c}-0.16^{* *} \\
(0.08\end{array}$ & $\begin{array}{c}0.11^{* * *} \\
(0.02)\end{array}$ & $\begin{array}{c}-0.27 * * * \\
(0.07)\end{array}$ & $\begin{array}{c}-0.33^{* * *} \\
(0.13)\end{array}$ & $\begin{array}{l}0.09 * \\
(0.05)\end{array}$ & $\begin{array}{c}-0.42^{* * *} \\
(0.12)\end{array}$ & $\begin{array}{l}-0.01 \\
(0.05)\end{array}$ & $\begin{array}{c}0.11^{* * *} \\
(0.03)\end{array}$ & $\begin{array}{c}-0.12 * * \\
(0.06)\end{array}$ \\
\hline $\begin{array}{l}\text { Technicians and assoc. Profess. } \\
\text { Clerical support workers }\end{array}$ & $\begin{array}{l}-0.05 \\
(0.07\end{array}$ & $\begin{array}{c}-0.03 \\
(0.02) \\
\text { Reference }\end{array}$ & $\begin{array}{l}-0.02 \\
(0.06)\end{array}$ & $\begin{array}{c}-0.23 * \\
(0.13)\end{array}$ & $\begin{array}{c}-0.03 \\
(0.04) \\
\text { Reference }\end{array}$ & $\begin{array}{l}-0.20^{*} \\
(0.12)\end{array}$ & $\begin{array}{l}-0.03 \\
(0.05)\end{array}$ & $\begin{array}{c}-0.04 \\
(0.02) \\
\text { Reference }\end{array}$ & $\begin{array}{c}0.01 \\
(0.05)\end{array}$ \\
\hline Service and sales workers & $\begin{array}{c}-0.31^{* * *} \\
(0.08\end{array}$ & $\begin{array}{c}-0.28 * * * \\
(0.03)\end{array}$ & $\begin{array}{l}-0.03 \\
(0.06)\end{array}$ & $\begin{array}{c}-0.33^{* * *} \\
(0.12)\end{array}$ & $\begin{array}{c}-0.21^{* * *} \\
(0.04)\end{array}$ & $\begin{array}{c}-0.12) \\
(0.10\end{array}$ & $\begin{array}{l}-0.01 \\
(0.04)\end{array}$ & $\begin{array}{c}-0.13^{* * *} \\
(0.04)\end{array}$ & $\begin{array}{c}0.11^{* *} \\
(0.06)\end{array}$ \\
\hline Craft and related trades workers & $\begin{array}{c}-0.49 * * * \\
(0.06\end{array}$ & $\begin{array}{c}-0.34^{* * *} \\
(0.02)\end{array}$ & $\begin{array}{c}-0.14^{* * *} \\
(0.05)\end{array}$ & $\begin{array}{c}-0.43^{* * *} \\
(0.11)\end{array}$ & $\begin{array}{c}-0.26^{* * *} \\
(0.03)\end{array}$ & $\begin{array}{l}-0.17^{*} \\
(0.10)\end{array}$ & $\begin{array}{c}-0.09 * * \\
(0.04)\end{array}$ & $\begin{array}{c}-0.21^{* * *} \\
(0.03)\end{array}$ & $\begin{array}{c}0.13^{* *} \\
(0.05)\end{array}$ \\
\hline Plant and machine oper., assemblers & $\begin{array}{c}-0.33 * * * \\
(0.06\end{array}$ & $\begin{array}{c}-0.29 * * * \\
(0.02)\end{array}$ & $\begin{array}{l}-0.03 \\
(0.05)\end{array}$ & $\begin{array}{c}-0.23^{* *} \\
(0.11)\end{array}$ & $\begin{array}{c}-0.20^{* * *} \\
(0.03)\end{array}$ & $\begin{array}{l}-0.02 \\
(0.10)\end{array}$ & $\begin{array}{l}-0.06 \\
(0.04)\end{array}$ & $\begin{array}{c}-0.23^{* * *} \\
(0.03)\end{array}$ & $\begin{array}{c}0.17 * * * \\
(0.05)\end{array}$ \\
\hline Elementary occupations & $\begin{array}{c}-0.41 * * * \\
(0.06\end{array}$ & $\begin{array}{c}-0.33^{* * *} \\
(0.02)\end{array}$ & $\begin{array}{l}-0.08 \\
(0.06)\end{array}$ & $\begin{array}{c}-0.36 * * * \\
(0.12)\end{array}$ & $\begin{array}{c}-0.29 * * * \\
(0.04)\end{array}$ & $\begin{array}{l}-0.07 \\
(0.10)\end{array}$ & $\begin{array}{l}-0.09 \\
(0.06)\end{array}$ & $\begin{array}{c}-0.24^{* * *} \\
(0.03)\end{array}$ & $\begin{array}{c}0.15^{* *} \\
(0.07)\end{array}$ \\
\hline $\begin{array}{l}\text { R squared } \\
\text { Overall model significance (p-value) } \\
\text { Flat profile (p-value) }\end{array}$ & $\begin{array}{l}0.30 \\
0.00 \\
0.00\end{array}$ & $\begin{array}{l}0.67 \\
0.00 \\
0.00\end{array}$ & $\begin{array}{l}0.09 \\
0.00 \\
0.00\end{array}$ & $\begin{array}{l}0.27 \\
0.00 \\
0.00\end{array}$ & $\begin{array}{l}0.65 \\
0.00 \\
0.00\end{array}$ & $\begin{array}{l}0.06 \\
0.00 \\
0.00\end{array}$ & $\begin{array}{l}0.04 \\
0.00 \\
0.62\end{array}$ & $\begin{array}{l}0.56 \\
0.00 \\
0.00\end{array}$ & $\begin{array}{l}0.00 \\
0.00 \\
0.00\end{array}$ \\
\hline Observations & 5,459 & 5,459 & 5,459 & 5,459 & 5,459 & 5,459 & 5,459 & 5,459 & 5,459 \\
\hline
\end{tabular}

All standard errors are robust and in parentheses. All models control for age and educational composition of the firm's workforce, share of female employees, conventional work hours and share of non-standard contracts. Pooled OLS and between models also control for firm size, firm vintage age and industry (for modalities of control variables see Table 3). Pooled OLS and within models include time dummies. The following diagnostic tests are presented: overall model significance $=$ Chi-squared for OLS, F-test for between and fixed-effects; flat profile = Wald test for OLS, F-test for between and fixed-effects regressions testing hypothesis that all occupation coefficients are jointly equal to zero. Columns 3, 6 and 9 refer to the regression with the difference between added-value and wage as dependant variable. 
Tab. A.1: Dynamic specification of baseline models.

\begin{tabular}{|c|c|c|c|c|c|c|}
\hline & \multicolumn{3}{|c|}{ Pooled OLS } & \multicolumn{3}{|c|}{ Fixed effects (within) } \\
\hline & $\begin{array}{c}1 \\
\text { value added } \\
\end{array}$ & $\begin{array}{c}2 \\
\text { wage }\end{array}$ & $\begin{array}{c}3 \\
\text { gap }\end{array}$ & $\begin{array}{c}4 \\
\text { value added } \\
\end{array}$ & $\begin{array}{c}5 \\
\text { wage }\end{array}$ & $\begin{array}{c}6 \\
\text { gap }\end{array}$ \\
\hline Managers & $\begin{array}{c}0.05 \\
(0.08)\end{array}$ & $\begin{array}{c}0.31 * * * \\
(0.04)\end{array}$ & $\begin{array}{c}-0.22 * * \\
(0.09)\end{array}$ & $\begin{array}{c}0.05 \\
(0.08)\end{array}$ & $\begin{array}{c}0.34 * * * \\
(0.05)\end{array}$ & $\begin{array}{c}-0.31^{* * *} \\
(0.09)\end{array}$ \\
\hline Professionals & $\begin{array}{l}-0.05 \\
(0.03)\end{array}$ & $\begin{array}{c}0.04^{* *} \\
(0.02)\end{array}$ & $\begin{array}{c}-0.09 * * \\
(0.04)\end{array}$ & $\begin{array}{l}-0.01 \\
(0.05)\end{array}$ & $\begin{array}{c}0.11^{* * *} \\
(0.03)\end{array}$ & $\begin{array}{c}-0.12^{* *} \\
(0.06)\end{array}$ \\
\hline Technicians and assoc. Profess. & $\begin{array}{c}0.04 \\
(0.03)\end{array}$ & $\begin{array}{c}-0.04 * * \\
(0.02)\end{array}$ & $\begin{array}{l}0.07 * \\
(0.04)\end{array}$ & $\begin{array}{l}-0.02 \\
(0.05)\end{array}$ & $\begin{array}{l}-0.04^{*} \\
(0.02)\end{array}$ & $\begin{array}{c}0.01 \\
(0.05)\end{array}$ \\
\hline Clerical support workers & & eference & & & Reference & \\
\hline Service and sales workers & $\begin{array}{l}-0.06 \\
(0.04)\end{array}$ & $\begin{array}{c}-0.12^{* * *} \\
(0.02)\end{array}$ & $\begin{array}{c}0.00 \\
(0.04)\end{array}$ & $\begin{array}{l}-0.01 \\
(0.04)\end{array}$ & $\begin{array}{c}-0.12^{* * *} \\
(0.04)\end{array}$ & $\begin{array}{c}0.12 * * \\
(0.06)\end{array}$ \\
\hline Craft and related trades workers & $\begin{array}{c}-0.08 * * \\
(0.04)\end{array}$ & $\begin{array}{c}-0.13^{* * *} \\
(0.02)\end{array}$ & $\begin{array}{l}-0.03 \\
(0.03)\end{array}$ & $\begin{array}{l}-0.08 * \\
(0.04)\end{array}$ & $\begin{array}{c}-0.21^{* * *} \\
(0.03)\end{array}$ & $\begin{array}{c}0.13^{* * *} \\
(0.05)\end{array}$ \\
\hline Plant and machine oper., assemblers & $\begin{array}{l}-0.05 \\
(0.03)\end{array}$ & $\begin{array}{c}-0.12 * * * \\
(0.02)\end{array}$ & $\begin{array}{c}0.00 \\
(0.03)\end{array}$ & $\begin{array}{l}-0.05 \\
(0.04)\end{array}$ & $\begin{array}{c}-0.23^{* * *} \\
(0.03)\end{array}$ & $\begin{array}{c}0.17 * * * \\
(0.05)\end{array}$ \\
\hline Elementary occupations & $\begin{array}{c}0.09 * * \\
(0.04)\end{array}$ & $\begin{array}{c}-0.14^{* * *} \\
(0.02)\end{array}$ & $\begin{array}{l}-0.02 \\
(0.04)\end{array}$ & $\begin{array}{l}-0.08 \\
(0.06)\end{array}$ & $\begin{array}{c}-0.24^{* * *} \\
(0.03)\end{array}$ & $\begin{array}{c}0.16^{* *} \\
(0.07)\end{array}$ \\
\hline One year lag of dependent variable & $\begin{array}{c}0.80 * * * \\
(0.04)\end{array}$ & $\begin{array}{c}0.61 * * * \\
(0.01)\end{array}$ & $\begin{array}{c}0.70 * * * \\
(0.05)\end{array}$ & $\begin{array}{c}0.10^{* * *} \\
(0.03)\end{array}$ & $\begin{array}{c}-0.08^{* * * *} \\
(0.02)\end{array}$ & $\begin{array}{c}0.05 \\
(0.03)\end{array}$ \\
\hline $\begin{array}{l}\text { R squared } \\
\text { Overall model significance } \\
\text { Flat profile }\end{array}$ & $\begin{array}{l}0.73 \\
0.00 \\
0.08\end{array}$ & $\begin{array}{l}0.83 \\
0.00 \\
0.00\end{array}$ & $\begin{array}{l}0.19 \\
0.00 \\
0.00\end{array}$ & $\begin{array}{l}0.60 \\
0.00 \\
0.73\end{array}$ & $\begin{array}{l}0.45 \\
0.00 \\
0.00\end{array}$ & $\begin{array}{l}0.06 \\
0.00 \\
0.00\end{array}$ \\
\hline Observations & 5,459 & 5,459 & 5,459 & 5,459 & 5,459 & 5,459 \\
\hline
\end{tabular}

All standard errors are robust and in parentheses. Both models include a lagged dependant variable among regressors and control for age and educational composition of the firm's workforce, share of female employees, conventional work hours, share of non-standard contracts and time dummies. Pooled OLS also controls for firm size, firm vintage age and industry (for modalities of control variables see Table 3). The following diagnostic tests are presented: overall model significance = Chi-squared for OLS, F-test for fixed-effects; flat profile = Wald test for OLS, F-test for fixed-effects regression testing hypothesis that all occupation coefficients are equal to zero. Columns 3 and 6 refer to the regression with the difference between added-value and wage as dependant variable. 
Tab. A.2: Dynamic specification in differences.

\begin{tabular}{|c|c|c|c|c|c|c|c|c|c|}
\hline & \multicolumn{3}{|c|}{ First differences (Without IV) ${ }^{\mathrm{a}}$} & \multicolumn{3}{|c|}{ Long differences (Without IV) ${ }^{\mathrm{b}}$} & \multicolumn{3}{|c|}{ First differences (With IV/ GMM) } \\
\hline & $\begin{array}{c}1 \\
\text { value added }\end{array}$ & $\begin{array}{c}2 \\
\text { wage }\end{array}$ & $\begin{array}{c}3 \\
\text { gap }\end{array}$ & $\begin{array}{c}4 \\
\text { value added }\end{array}$ & $\begin{array}{c}5 \\
\text { wage }\end{array}$ & $\begin{array}{c}6 \\
\text { gap }\end{array}$ & $\begin{array}{c}7 \\
\text { value added }\end{array}$ & $\begin{array}{c}8 \\
\text { wage }\end{array}$ & $\begin{array}{c}9 \\
\text { gap }\end{array}$ \\
\hline Managers & $\begin{array}{l}-0.01 \\
(0.07)\end{array}$ & $\begin{array}{c}0.35 * * * \\
(0.03)\end{array}$ & $\begin{array}{c}-0.35^{* * *} \\
(0.08)\end{array}$ & $\begin{array}{c}-0.01 \\
(0.10)\end{array}$ & $\begin{array}{c}0.38 * * * \\
(0.04)\end{array}$ & $\begin{array}{c}-0.40 * * * \\
(0.11)\end{array}$ & $\begin{array}{c}0.00 \\
(0.15)\end{array}$ & $\begin{array}{r}0.28 * * * \\
(0.10)\end{array}$ & $\begin{array}{l}-0.27 \\
(0.17)\end{array}$ \\
\hline Professionals & $\begin{array}{c}0.01 \\
(0.03)\end{array}$ & $\begin{array}{c}0.10^{* * * *} \\
(0.02)\end{array}$ & $\begin{array}{c}-0.09 * * \\
(0.04)\end{array}$ & $\begin{array}{c}-0.05 \\
(0.06)\end{array}$ & $\begin{array}{l}0.12 * * * \\
(0.02)\end{array}$ & $\begin{array}{c}-0.17 * * * \\
(0.06)\end{array}$ & $\begin{array}{l}-0.07 \\
(0.11)\end{array}$ & $\begin{array}{c}0.11^{* *} \\
(0.06)\end{array}$ & $\begin{array}{l}-0.18 \\
(0.13)\end{array}$ \\
\hline $\begin{array}{l}\text { Technicians and assoc. Profess. } \\
\text { Clerical support workers }\end{array}$ & $\begin{array}{c}0.03 \\
(0.03)\end{array}$ & $\begin{array}{c}-0.04^{*} \\
(0.02) \\
\text { Reference }\end{array}$ & $\begin{array}{l}0.07 * \\
(0.04)\end{array}$ & $\begin{array}{c}-0.06 \\
(0.06)\end{array}$ & $\begin{array}{c}-0.02 \\
(0.02) \\
\text { Reference }\end{array}$ & $\begin{array}{l}-0.04 \\
(0.06)\end{array}$ & $\begin{array}{c}0.03 \\
(0.08)\end{array}$ & $\begin{array}{r}-0.02 \\
(0.04) \\
\text { Reference }\end{array}$ & $\begin{array}{c}0.05 \\
(0.09)\end{array}$ \\
\hline Service and sales workers & $\begin{array}{c}0.01 \\
(0.04)\end{array}$ & $\begin{array}{c}-0.10^{* * *} \\
(0.02)\end{array}$ & $\begin{array}{c}0.11^{* *} \\
(0.05)\end{array}$ & $\begin{array}{c}0.01 \\
(0.06)\end{array}$ & $\begin{array}{c}-0.09 * * * \\
(0.03)\end{array}$ & $\begin{array}{c}0.10 \\
(0.06)\end{array}$ & $\begin{array}{c}0.16 \\
(0.15)\end{array}$ & $\begin{array}{l}-0.04 \\
(0.09)\end{array}$ & $\begin{array}{c}0.19 \\
(0.18)\end{array}$ \\
\hline Craft and related trades workers & $\begin{array}{l}-0.01 \\
(0.03)\end{array}$ & $\begin{array}{c}-0.19 * * * \\
(0.02)\end{array}$ & $\begin{array}{c}0.18^{* * *} \\
(0.04)\end{array}$ & $\begin{array}{c}-0.06 \\
(0.05)\end{array}$ & $\begin{array}{c}-0.18 * * * \\
(0.02)\end{array}$ & $\begin{array}{l}0.11^{*} \\
(0.06)\end{array}$ & $\begin{array}{l}0.34^{*} \\
(0.18)\end{array}$ & $\begin{array}{c}-0.24^{* * *} \\
(0.06)\end{array}$ & $\begin{array}{c}0.58 * * * \\
(0.19)\end{array}$ \\
\hline Plant and machine oper., assemblers & $\begin{array}{l}-0.01 \\
(0.03)\end{array}$ & $\begin{array}{c}-0.19 * * * \\
(0.02)\end{array}$ & $\begin{array}{c}0.18^{* * *} \\
(0.04)\end{array}$ & $\begin{array}{c}-0.02 \\
(0.05)\end{array}$ & $\begin{array}{c}-0.19 * * * \\
(0.02)\end{array}$ & $\begin{array}{c}0.17 * * * \\
(0.06)\end{array}$ & $\begin{array}{c}0.35^{* *} \\
(0.18)\end{array}$ & $\begin{array}{c}-0.22^{* * *} \\
(0.07)\end{array}$ & $\begin{array}{c}0.57 * * * \\
(0.19)\end{array}$ \\
\hline Elementary occupations & $\begin{array}{l}-0.03 \\
(0.03)\end{array}$ & $\begin{array}{c}-0.20 * * * \\
(0.02)\end{array}$ & $\begin{array}{c}0.16^{* * *} \\
(0.04)\end{array}$ & $\begin{array}{c}-0.06 \\
(0.05)\end{array}$ & $\begin{array}{c}-0.19 * * * \\
(0.03)\end{array}$ & $\begin{array}{c}0.12^{* *} \\
(0.06)\end{array}$ & $\begin{array}{l}0.31 * \\
(0.16)\end{array}$ & $\begin{array}{c}-0.23^{* * *} \\
(0.06)\end{array}$ & $\begin{array}{c}0.52 * * * \\
(0.17)\end{array}$ \\
\hline One year lag of dependent variable & $\begin{array}{c}-0.34^{* * *} \\
(0.08) \\
\end{array}$ & $\begin{array}{c}-0.32^{* * * *} \\
(0.07)\end{array}$ & $\begin{array}{c}-0.36 * * * \\
(0.07) \\
\end{array}$ & $\begin{array}{c}0.13^{* * *} \\
(0.03)\end{array}$ & $\begin{array}{c}0.06^{* * *} \\
(0.02)\end{array}$ & $\begin{array}{c}0.11^{* * *} \\
(0.03)\end{array}$ & $\begin{array}{c}-0.34^{* * *} \\
(0.08)\end{array}$ & $\begin{array}{c}-0.32^{* * *} \\
(0.02)\end{array}$ & $\begin{array}{c}-0.35^{* * *} \\
(0.07)\end{array}$ \\
\hline $\begin{array}{l}\text { Adjusted R squared } \\
\text { Overall model significance } \\
\text { Flat profile }\end{array}$ & $\begin{array}{l}0.12 \\
0.00 \\
0.89\end{array}$ & $\begin{array}{l}0.42 \\
0.00 \\
0.00\end{array}$ & $\begin{array}{l}0.18 \\
0.00 \\
0.00\end{array}$ & $\begin{array}{l}0.02 \\
0.00 \\
0.61\end{array}$ & $\begin{array}{l}0.33 \\
0.00 \\
0.00\end{array}$ & $\begin{array}{l}0.06 \\
0.00 \\
0.00\end{array}$ & $\begin{array}{l}0.10 \\
0.00 \\
0.72\end{array}$ & $\begin{array}{l}0.41 \\
0.00 \\
0.00\end{array}$ & $\begin{array}{l}0.16 \\
0.00 \\
0.10\end{array}$ \\
\hline Underidenditifcation & & & & & & & 0.00 & 0.00 & 0.00 \\
\hline Weak identification & & & & & & & 17.49 & 15.99 & 17.64 \\
\hline Endogeneity & & & & & & & 0.47 & 0.57 & 0.19 \\
\hline Observations & 5,459 & 5,459 & 5,459 & 3654 & 3654 & 3654 & 5,459 & 5,459 & 5,459 \\
\hline
\end{tabular}


All standard errors are robust and in parentheses. First differences of occupational shares are instrumented with one-period lags of levels of occupational shares. Both models include a lagged dependant variable among regressors and control for age and educational composition of the firm's workforce, share of female employees, conventional work hours, share of non-standard contracts and time dummies (for modalities of control variables see Table 3). The following diagnostic tests are presented: overall model significance $=$ Chi-squared for model without IV, F-test for GMM-IV; flat profile $=$ Wald test testing hypothesis that all occupation coefficients are equal to zero; underidentification = test based on Kleibergen-Paap rk LM statistic; weak identification = Kleibergen-Paap rk Wald F statistic; endogneity = test based on difference of Sargan-Hansen statistics. Column 3 and 6 refer to the regression with the difference between added-value and wage as dependant variable. ${ }^{\mathrm{a}}$ Differences based on year-to-year changes. ${ }^{\mathrm{b}}$ Differences based on changes between $t$ and $t-2$. 
Tab. A.3: Overall, between and within dispersion of main variables

\begin{tabular}{|c|c|c|}
\hline & Mean & Standard deviation \\
\hline \multicolumn{3}{|l|}{ Log added value per hour } \\
\hline overall & 3.76 & 0.56 \\
\hline between & & 0.54 \\
\hline within & & 0.19 \\
\hline \multicolumn{3}{|l|}{ Log mean wage per hour } \\
\hline overall & 2.78 & 0.26 \\
\hline between & & 0.26 \\
\hline within & & 0.08 \\
\hline \multicolumn{3}{|c|}{ Occupational shares in hours worked } \\
\hline \multicolumn{3}{|l|}{ Managers } \\
\hline overall & 0.04 & 0.07 \\
\hline between & & 0.06 \\
\hline within & & 0.04 \\
\hline \multicolumn{3}{|l|}{ Professionals } \\
\hline overall & 0.11 & 0.19 \\
\hline between & & 0.19 \\
\hline within & & 0.07 \\
\hline \multicolumn{3}{|l|}{ Technicians and associate professionals } \\
\hline overall & 0.09 & 0.15 \\
\hline between & & 0.14 \\
\hline within & & 0.07 \\
\hline \multicolumn{3}{|l|}{ Clerical support workers } \\
\hline overall & 0.18 & 0.19 \\
\hline between & & 0.19 \\
\hline within & & 0.09 \\
\hline \multicolumn{3}{|l|}{ Service and sales workers } \\
\hline overall & 0.04 & 0.15 \\
\hline between & & 0.16 \\
\hline within & & 0.06 \\
\hline \multicolumn{3}{|l|}{ Craft and related trades workers } \\
\hline overall & 0.23 & 0.31 \\
\hline between & & 0.29 \\
\hline within & & 0.13 \\
\hline \multicolumn{3}{|l|}{ Plant and machine operators, and assemblers } \\
\hline overall & 0.22 & 0.30 \\
\hline between & & 0.28 \\
\hline within & & 0.12 \\
\hline \multicolumn{3}{|l|}{ Elementary occupations } \\
\hline overall & 0.09 & 0.19 \\
\hline between & & 0.19 \\
\hline within & & 0.09 \\
\hline
\end{tabular}

All statistics are based on the same sample of 1735 firms and 5,459 firm-year observations, meaning that every firm is on average observed 3.15 times during the observation period from 1999-2006. 